\title{
Revisions to the Nomenclature for Kansas Aquifers
}

\author{
P. Allen Macfarlane \\ Kansas Geological Survey, 1930 Constant Avenue, Lawrence, Kansas 66047-3726
}

\begin{abstract}
The nomenclature for Kansas aquifers needs revision. Many of the names currently in use were derived in an ad hoc manner without the benefit of a consistent set of hydrogeologically based guidelines. Because nomenclature forms the basis of scientific discussion of hydrologic issues, names should be clearly defined and consistently applied in order to prevent erroneous or unintended hydrologic interpretations. The nomenclature revisions presented in this paper are based on the guidelines developed by the U.S. Geological Survey's Water Resources Division (Laney and Davidson, 1986). According to these guidelines, aquifer names should be based on lithologic, lithostratigraphic, or geographic names. The following new aquifer names are recognized in Kansas: glacial drift aquifer, Niobrara aquifer, Morrison-Dockum aquifer, Day Creek aquifer, Cedar Hills-upper Salt Plain aquifer, Wellington aquifer, Flint Hills aquifer, Osage Cuestas aquifer system, and Ozark Plateau aquifer system.
\end{abstract}

\section{Introduction}

An essential part of any ground-water investigation is to define and map aquifer and confining units (hydrostratigraphic units) in the subsurface of the study area. Delineation of these units subdivides the geologic framework on the basis of permeability and thus aids in the definition of the flow system. At present, however, there is no widely accepted hydrogeologic code for aquifer and confining-unit nomenclature (Seaber, 1988). The informal designation and delineation of hydrostratigraphic units can lead to confusion, if the process is not based on good scientific evidence and thoroughly documented. Attempts to recognize hydrostratigraphic units as formal entities in the stratigraphic code have met with limited success (P. R. Seaber, personal communication, 1995). Hydrostratigraphic units are considered informal economic units in the 1983 North American Stratigraphic Code (NACSN, 1983).

Over the last century, the names of Kansas aquifers have changed as our understanding of ground-water flow systems has improved. Unfortunately, the current assemblage of names for aquifer and confining units in Kansas is a mix of the older and the more recent nomenclature (fig. 1). These names derived from local to multistate regional studies of the Kansas Geological Survey (KGS) and the U.S. Geological Survey (USGS). In the 1980's, multistate hydrogeologic investigations of the water-bearing deposits of the Kansas subsurface were conducted by the Regional Aquifer Systems Analysis (RASA) program of the USGS.
In the Central Midwest RASA project, many of the principal aquifers in Kansas were renamed to reflect largescale hydraulic continuity across state lines, and the major confining unit systems in Kansas were given names for the first time (Jorgensen et al., 1993). However, the less prolific bedrock aquifers in Jurassic through Pennsylvanian rocks were included as part of a more extensive confining unit and were not specifically identified.

In an editorial entitled "Aquifer Names," Jorgensen (1982) argued that the lack of a sound nomenclature fosters misconceptions that may lead to erroneous or unintended hydrologic interpretations. Many of the laws and regulations that pertain to ground water are written by those with no hydrogeological training, who may not recognize the consequences of using a faulty system of nomenclature. In at least one instance in Kansas, State agency regulations designated ground-water sources using the formation names rather than hydrostratigraphic names, which implies that (1) the entire unit acts as an aquifer and (2) there is no hydraulic connection between adjacent permeable units.

The use of stratigraphic names for hydrostratigraphic units is particularly problematic where repeated cycles of alluviation and erosion have resulted in vertically stacked and amalgamated cut-and-fill sequences in the Ogallala Formation and the Quaternary deposits in western Kansas. The resulting complex subsurface stratigraphy is difficult to unravel using the limited information contained in driller's logs. In southwest Kansas, it is extremely difficult to identify the Quaternary-Pliocene unconformity in the 


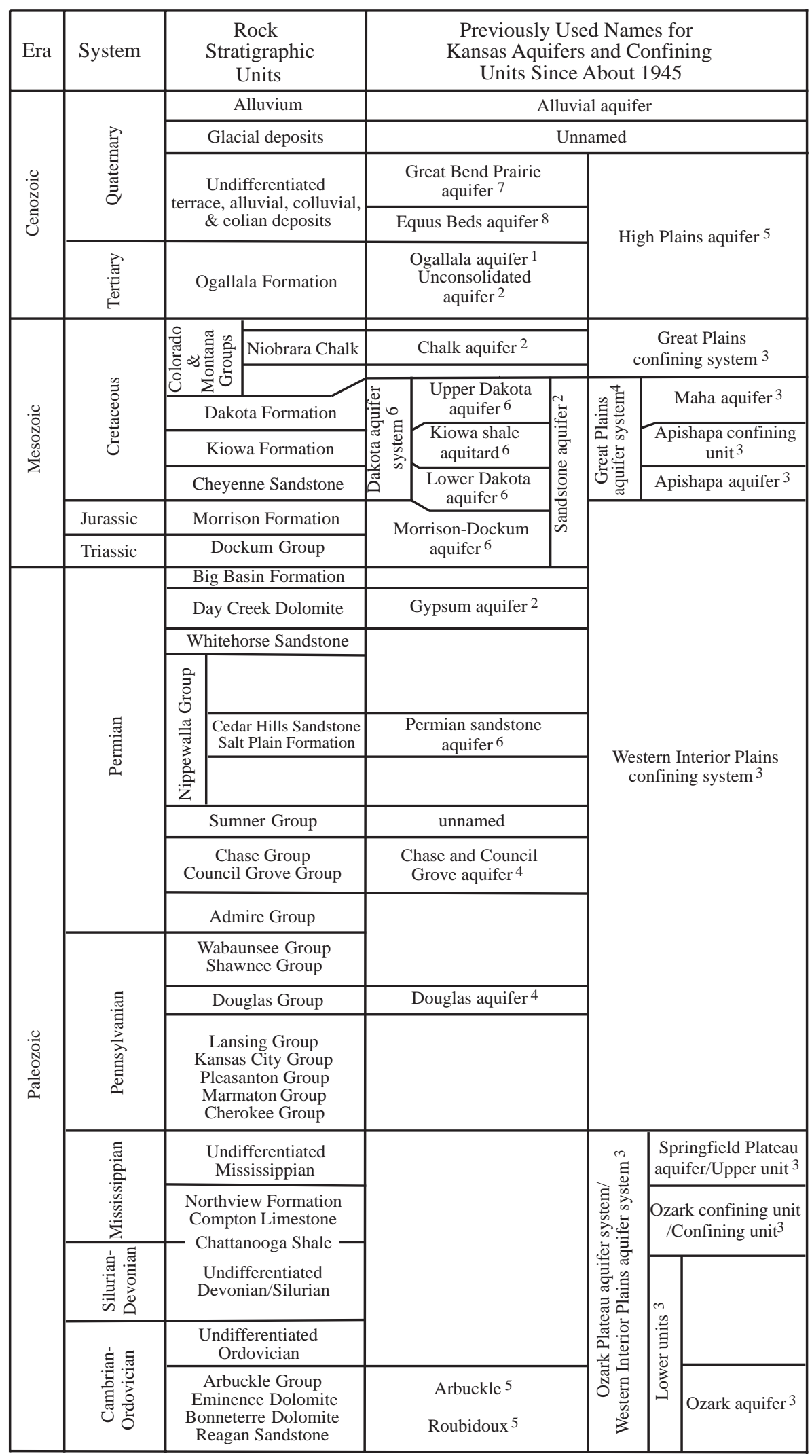

Figure 1. Previously used names for aquifer and confining units in Kansas. Sources: 1 = O'Connor and McClain, 1981; $2=$ Gugentag et al., 1981; 3 = Jorgensen et al., 1993; 4 = U.S. Geological Survey, 1985; 5 = Macfarlane and Hathaway, 1987; $6=$ Macfarlane, 1993; 7 = Sophocleous, 1998; and Williams and Lohman, 1949. 
subsurface without detailed study of the fossils preserved in these sediments or use of fission-track or other radiometric dating of the sediments (Bayne et al., 1976).

The purpose of this paper is to propose a nomenclature for the aquifer units that are present in the Kansas subsurface using the guidelines proposed by Laney and Davidson (1986). An aquifer is considered to be significant if it yields water to wells at rates equal to or greater than 50 gallons per minute (gpm) or if it supplies water for industry, agriculture, or human consumption.

\section{Hydrostratigraphic Unit Delineation}

Hydrostratigraphic units were originally defined by Maxey (1964) as bodies of rock with considerable lateral extent that act as a reasonably distinct hydrologic system. It is clear from Maxey's definition that hydrostratigraphic units were to be hydraulically continuous, mappable, and scale-independent entities. Mappability, in this case, means the subsurface geology can be subdivided according to permeability (Seaber, 1988). Thus, a single hydrostratigraphic unit may include a formation, part of a formation, or a group of formations.

From smallest to largest, the terms used to classify water-yielding rocks are zone, aquifer, and aquifer system (Laney and Davidson, 1986, p. 4). The terms are purposely vague (Freeze and Cherry, 1979, p. 49), so as to be sufficiently flexible to meet a variety of hydrogeologic scales and settings as well as the needs of the project (Jorgensen, 1982). A zone is used to identify a segment of an aquifer with a particular hydrologic characteristic that is not typical of the entire aquifer. An example of a zone is a highly permeable subunit of a regional aquifer that is traceable over an area covering tens to hundreds of square miles. An aquifer was defined by Lohman et al. (1972, p. 2) as "a formation, group of formations, or a part of a formation that contains sufficient saturated permeable material to yield significant quantities of water to wells and springs." Fetter (1994) suggested that to be an aquifer, the rock unit should have an intrinsic permeability of at least 0.01 darcy or a hydraulic conductivity of about 0.03 $\mathrm{ft} /$ day. An aquifer system was originally defined by Poland et al. (1972, p. 5) as "a heterogeneous body of intercalated permeable and poorly permeable material that functions as water-yielding hydraulic unit; it comprises two or more permeable beds separated at least locally by aquitards that impede ground-water movement but do not greatly affect the hydraulic continuity of the system." Laney and Davidson (1986) suggest that the definition could be made more general if the term "aquifers" was substituted for the term "permeable beds." A confining unit was defined in Lohman and others (1972, p. 5) to be equivalent to the terms aquitard and aquiclude and has been used in U.S. Geological Survey reports since 1972 (Seaber, 1988). Jorgensen et al. (1993, p. B42) described an aquifer system as consisting of "two or more aquifers in the same hydraulic system, which are separated at most locations by one or more confining units." Likewise, they defined a confining system as "two or more confining units separated at most locations by one or more aquifers that are not in the same hydraulic system" (p. B42).

\section{The Laney and Davidson (1986) Guidelines}

The guidelines used to designate the proposed names for Kansas aquifer units in this paper are the same guidelines for aquifer nomenclature outlined for U.S. Geological Survey personnel in Laney and Davidson (1986). These guidelines resulted from informal discussions with hydrologists and hydrogeologists with the Water Resources Division and represent a consensus of opinion.

Laney and Davidson (1986) suggested two possible courses of action concerning the naming of aquifer units. The simplest is to leave aquifer units unnamed to avoid the unnecessary coining of new aquifer names. Not naming aquifer units is appropriate in areas where no formal lithostratigraphic units have been identified or where the hydrogeology is poorly known.

If, however, aquifers are to be named, the names should be based on lithologic, lithostratigraphic, or geographic names. Lithology-derived names are useful where there are no formally recognized lithostratigraphic units in the part of the section of interest. The adjectives for these aquifer names are based on lithologic terms (e.g., sand and gravel aquifer) and may be particularly useful for naming aquifers in glacial deposits. Lithostratigraphic names are appropriate for aquifers that may be statewide or more in extent-e.g., the Madison aquifer after the Madison Group of the northern Great Plains. Geographic names could be used as a basis for naming aquifers where no single lithostratigraphic name or combination of lithostratigraphic names would be appropriate, as in the Great Plains aquifer system of the U.S. Geological Survey's Central Midwest RASA project.

Laney and Davidson (1986) did not recommend deriving the names for aquifers or aquifer systems from the following sources: time-stratigraphic names, names based on relative position only, alphanumeric designation for model layers, depositional environment, depth of occurrence, acronyms, or hydrologic condition, such as confined or unconfined. They also did not recommend naming confining units unless such a name would add to the understanding of a complex aquifer system.

\section{Revisions to the Kansas Aquifer Nomenclature}

The revised aquifer nomenclature for Kansas proposed in this paper is shown in fig. 2, along with the stratigraphic column. A brief history of the evolution of individual Kansas aquifer names, as well as a summary of the basis for the proposed name, is given below. Information on the 


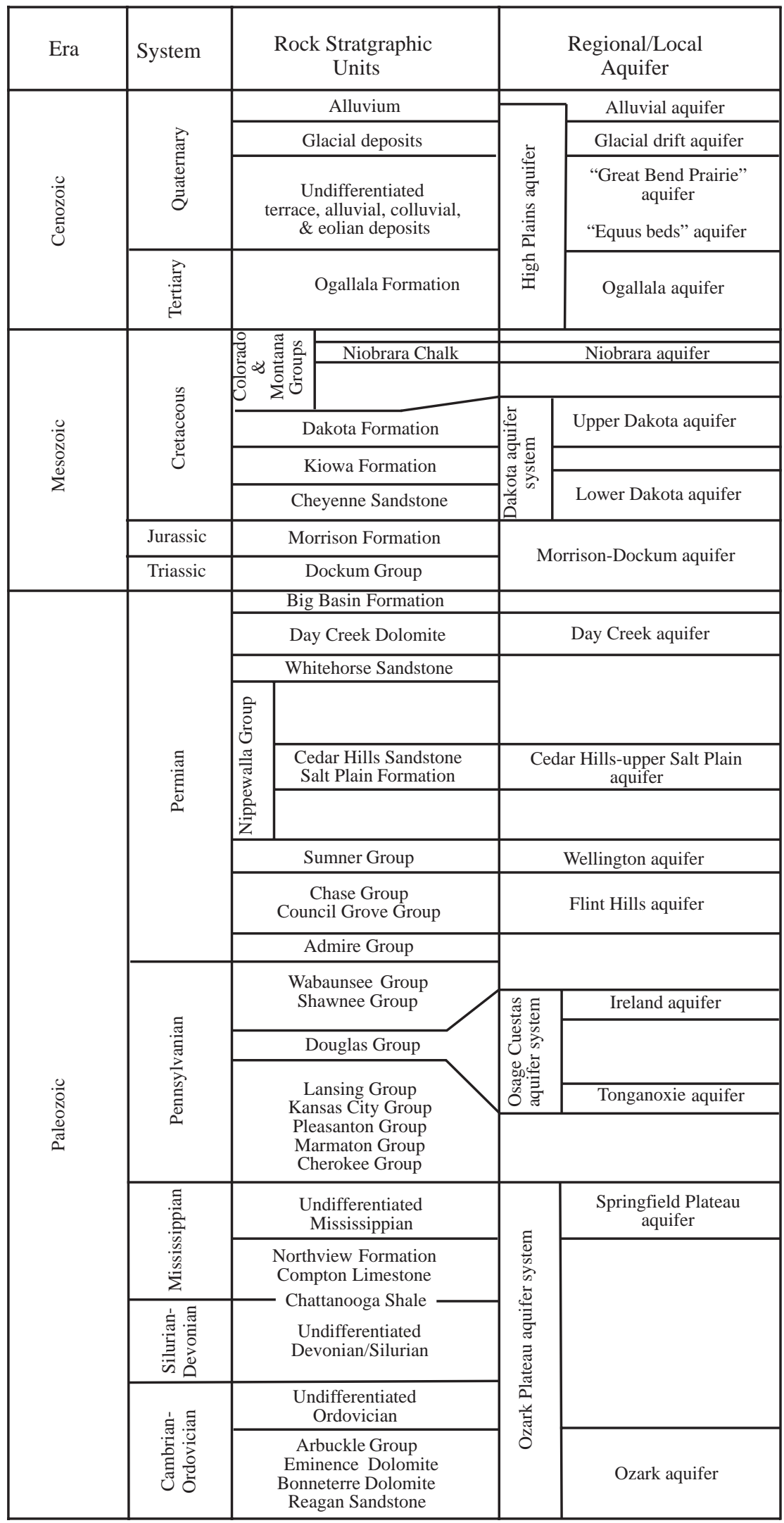

FIGURE 2. Revised nomenclature for Kansas aquifers, showing their component hydrostratigraphic units. 
history of lithostratigraphic names in Kansas can be found in Baars et al. (1998).

\section{Alluvial Aquifer}

Alluvium is a general term for clay, silt, sand, and gravel deposited during the Quaternary by streams in river valleys (Jackson, 1997). The alluvial aquifer includes the water-bearing alluvium adjacent to the stream and hydraulically connected aquifers in terrace deposits and associated alluvial Quaternary deposits in paleodrainages, such as in the Republican River valley in northern Jewell and Republic counties (Fader, 1968) (fig. 3). In Kansas, a separate alluvial aquifer is not distinguished where there is evidence of good hydraulic connection to either the underlying High Plains aquifer or glacial drift aquifer. Thus, a separate Arkansas River alluvial aquifer is present only from the Kansas-Colorado border to Ford County and from the city of Wichita south to the Kansas-Oklahoma border. In between, the Arkansas River alluvium is part of the High Plains aquifer. In the northeastern part of the state, alluvial aquifers are not distinguished in the Kansas River drainage where they overlie the glacial drift aquifer. The name of the river adjacent to the particular waterbearing alluvium is used to distinguish a specific alluvial aquifer (Laney and Davidson, 1986), as in the Kansas River alluvial aquifer.

\section{Glacial drift aquifer}

The glacial drift aquifer (fig. 4) consists of glacial drift and associated Quaternary alluvial and eolian deposits in northeastern Kansas (Denne et al., 1998). Aber (1988, 1991) recognized two tills in northeastern Kansas and assigned them to the Independence Formation, a new stratigraphic name that has not been formally recognized
(Baars, 1998). The diamicton and related deposits associated with the first advance of the glacier in Kansas during the Pleistocene are referred to the lower Independence Formation, whereas the glacial deposits associated with the second, more extensive advance of the glacier in Kansas are referred to the upper Independence Formation. Included with the glacial drift aquifer are the alluvial deposits in the Kansas River drainage that overlie and are hydraulically connected to the Independence Formation.

\section{High Plains aquifer}

As part of the USGS High Plains RASA project, the High Plains aquifer was defined as including "one or more hydraulically connected geologic units of late Tertiary or Quaternary age. In ascending order, the late Tertiary rocks consist of the Brule Formation, Arikaree Group, and Ogallala Formation. The Quaternary deposits consist of alluvial, dune sand, and valley-fill deposits" (Gutentag and Weeks, 1980, p. 1). In Kansas, the High Plains aquifer consists of the Ogallala Formation and hydraulically connected Quaternary deposits (fig. 4).

Over the last century, the names used to identify the High Plains aquifer have changed as our hydrogeologic perspective has become more regional. Early in the century, the High Plains aquifer was referred to by Haworth (1913) as the "Tertiary material," and later Moore (1940) classified the "Ogallala beds" as a significant water-bearing formation. By the 1940's, the KGS was conducting county reconnaissance studies of the geology and ground-water resources. In his report on Stanton County, Latta (1941) indicated that he could not distinguish between the Ogallala Formation and the Pleistocene deposits and thus considered them together as a single ground-water source. Beginning in the 1970's, hydrogeologic studies conducted by the KGS and the

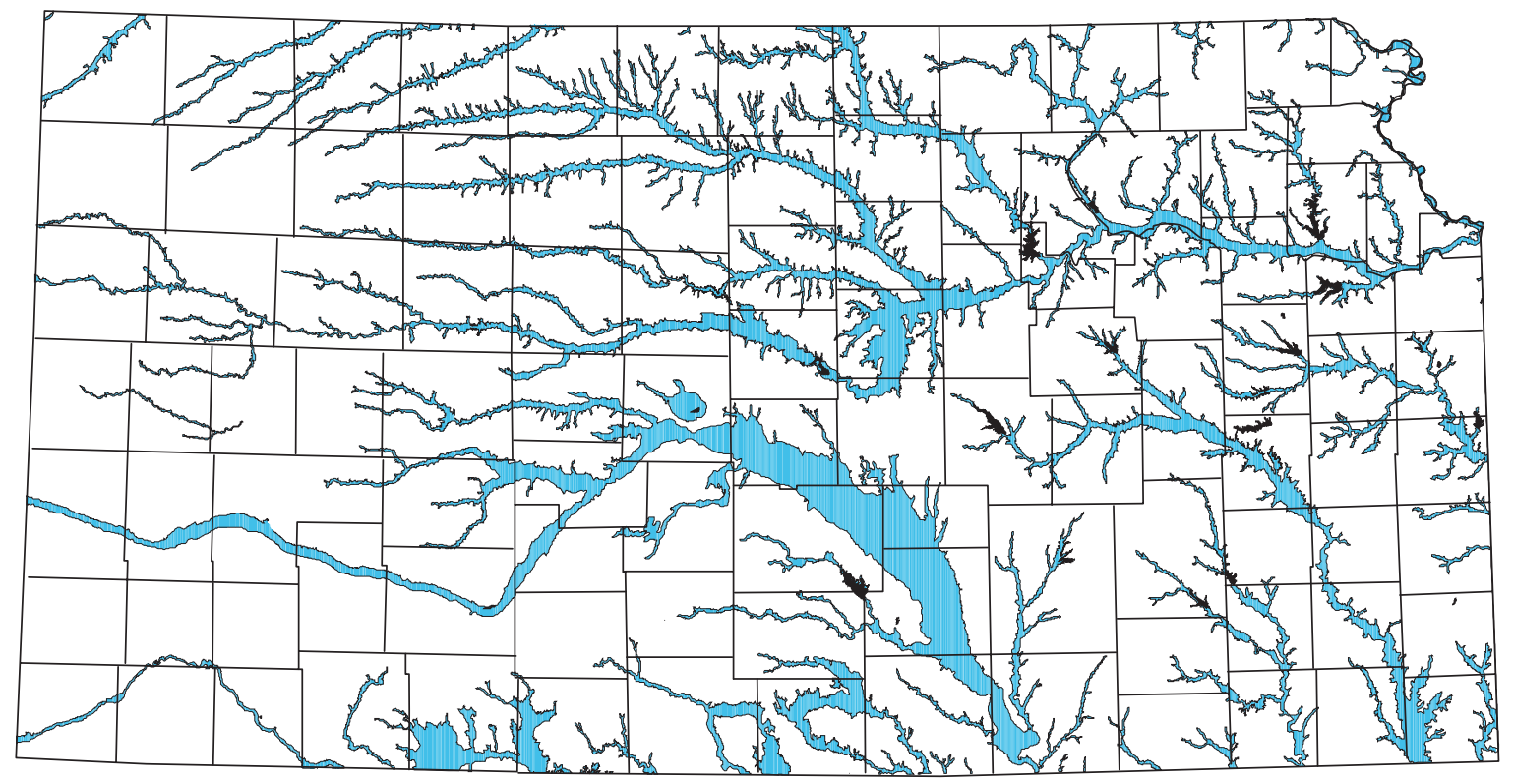

FIgURE 3. Extent of alluvial aquifers in Kansas. 


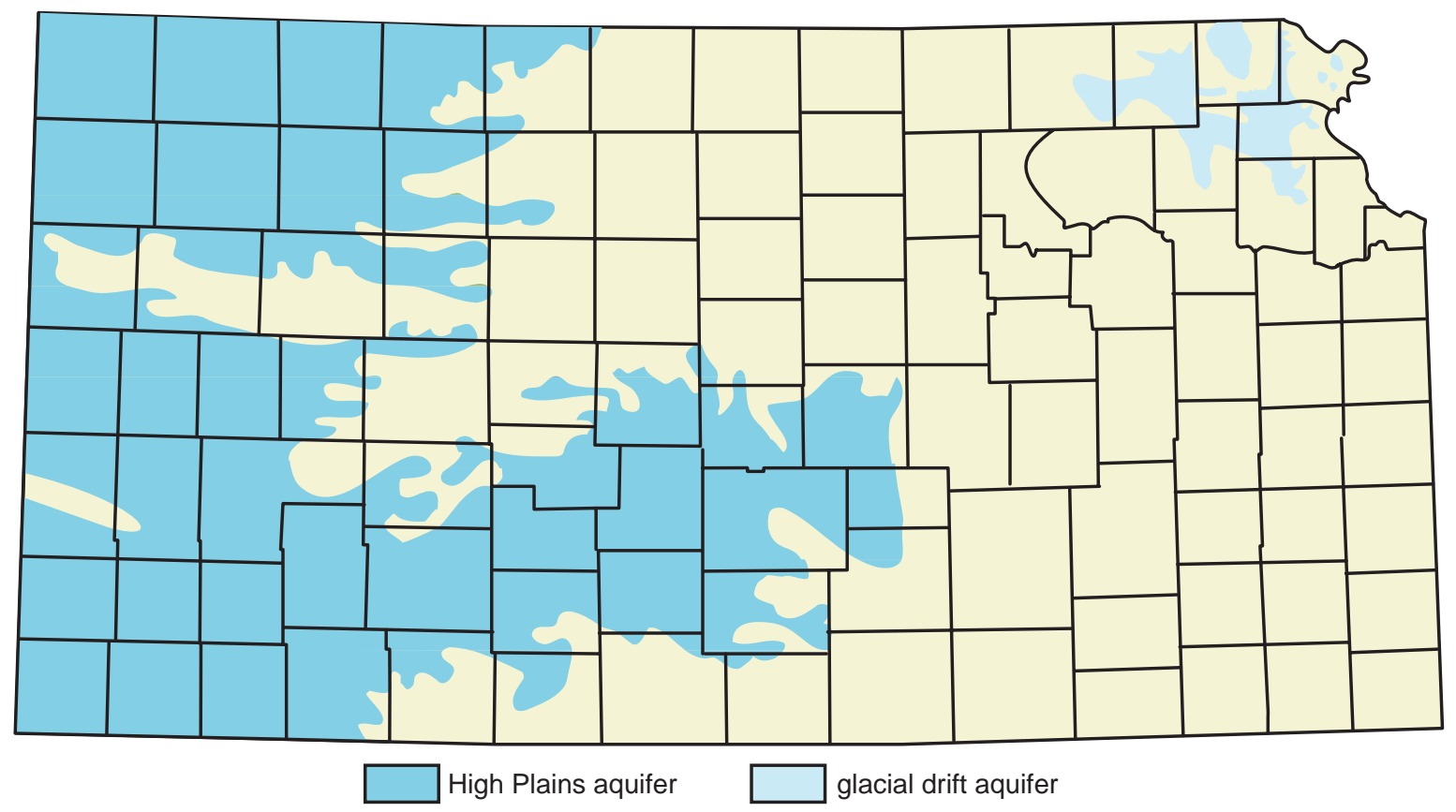

FIgURE 4. Extent of the High Plains and glacial drift aquifers in Kansas.

USGS became more regionally focused. Gutentag et al. (1981) reported on the results of a subregional hydrogeologic study of southwest Kansas and referred to the hydraulically connected Ogallala Formation, undifferentiated Pleistocene deposits, and Quaternary alluvium as the unconsolidated aquifer. O'Connor and McClain (1981) reported on the results of a regional hydrogeologic study of western Kansas for the Kansas Water Office. Their report contains one of the earliest published references to the Ogallala aquifer, which they defined as consisting of the "rocks of the Ogallala Formation together with the overlying water-saturated undifferentiated Pleistocene deposits which are hydraulically connected and form a single ground-water reservoir" (p. 1).

Where the High Plains aquifer locally consists only of the Ogallala Formation, it is appropriate to use the term Ogallala aquifer. The geologic units that constitute an unconfined aquifer also include the unsaturated deposits above the water table because the unsaturated zone is hydraulically connected to the saturated deposits below the water table. The name High Plains aquifer is applied to the regional aquifer in the Ogallala Formation and associated hydraulically connected undifferentiated Quaternary deposits, instead of the name Ogallala aquifer.

\section{"Great Bend Prairie" aquifer}

The "Great Bend Prairie" aquifer consists almost entirely of a thick sequence of hydraulically connected Quaternary alluvial and eolian deposits above the bedrock surface. This name was first used in formal publication by Sophocleous (1998) to identify a subregion of the High Plains aquifer south of the Arkansas River, in the Great
Bend Prairie region of south-central Kansas. Sophocleous (1998) defined the western boundary of this aquifer subregion based on Merriam's (1963) map, which shows the approximate boundary between the Tertiary and Quaternary deposits that overlie the bedrock in western and central Kansas. The eastern boundary of this subregion was fixed as the western boundary of what Sophocleous (1998) and earlier authors referred to as the Equus Beds aquifer (see below). This eastern boundary was drawn arbitrarily across the Arkansas River in eastern Reno County where the lateral extent of the Quaternary deposits in the north-south direction is narrowest.

In the first hydrogeologic study of the Great Bend Prairie (Fader and Stullken, 1978), the authors noted that the unconsolidated Pliocene and Pleistocene deposits comprised the region's principle aquifer. In 1984, the hydraulically connected Pleistocene deposits were named the Big Bend aquifer in a KGS internal report, and the aquifer's extent was defined using Merriam's (1963) map of the Cenozoic deposits above the bedrock surface.

Jorgensen et al. (1993) identified a south-central subregion of the Kansas High Plains aquifer, with arbitrary western and eastern boundaries that approximate those subsequently used by Sophocleous (1998).

The name "Great Bend Prairie" aquifer is considered a misnomer. The subsurface geology, aquifer properties, and continuity of the predevelopment water table suggest that the "Great Bend Prairie" aquifer is hydraulically well connected to the High Plains aquifer in southwest Kansas and to the High Plains aquifer to the east.

This aquifer name was based on a geographic region identified as the Great Bend Prairie by Adams (1903) and was used in subsequent publications (Fader and Stullken, 
1978; Self, 1978). However, Schoewe (1949) rejected this name for a geographic region because the term prairie is primarily a botanical term, denoting a tract of grassland and thus was unsuited for the naming of physiographic units. He renamed this region the Great Bend Lowland minor division, defined its extent, and considered it to be part of the Arkansas River Lowland section of the Central Lowland physiographic province. The Great Bend Prairie was also rejected as a physiographic subdivision by Fenneman (1946). Later publications (Wilson, 1978; Steeples and Buchanan, 1983) recognized only the physiographic subdivisions of Schoewe and did not identify a Great Bend Prairie region south of the Arkansas River. Hence, the geographic basis for the name "Great Bend Prairie aquifer" is somewhat doubtful and, when cited, should be in quotation marks to indicate its misnomer status.

\section{"Equus beds aquifer"}

The earliest reference to the Equus beds was published in Haworth and Beede (1897), where the Pleistocene-age fluvial deposits of the McPherson Formation that fill the McPherson Channel are referred to as the McPherson Equus beds. Haworth (1897) also indicated these beds were a potentially important ground-water source. Later, Williams and Lohman (1949) indicated that the "Equus beds" was referred to as an underground water source in an August 1924, letter to the Wichita city manager by G. W. Biggs, Jr., and C. E. Trowbridge. In 1984, an unpublished internal KGS report on water research in Kansas named the water-bearing Pleistocene deposits in parts of McPherson, Harvey, Sedgwick, Sumner, and Reno counties the Equus beds aquifer. The report arbitrarily defined the boundary between the Big Bend aquifer and the Equus beds aquifer to be where the lateral extent of the Pleistocene deposits is narrow in width and approximately coincides with the Arkansas River valley in eastern Reno County. In a report on the Kansas High Plains from the USGS RASA program, Stullken et al. $(1985$, p. 4) indicated that the Equus beds aquifer was a hydraulically connected subregion of the High Plains aquifer and placed its western boundary with the "Great Bend Prairie" aquifer slightly west of the boundary defined in the 1984 KGS report.

The name "Equus beds" aquifer is considered a misnomer because it is not derived from either a recognized lithostratigraphic unit or a geographic name, as prescribed in the guidelines in Laney and Davidson (1986). The Equus beds is not a formally recognized lithostratigraphic unit in Kansas (Zeller, 1968). It also is not an accepted geographic name. In his article on the geography of Kansas, Schoewe (1949) assigned McPherson County, along with most of the northwestern Harvey and extreme northeastern Reno counties, to the McPherson Lowland minor division of the Arkansas River Lowlands section, Central Lowland physiographic province. Southwestern Harvey, most of Sedgwick, and eastern Sumner counties were assigned to the Arkansas River Lowlands section of the Central Lowland physiographic province. Stramel (1956) made reference to the "Equus beds area" but did not define its extent. The boundaries of the Equus beds aquifer in Stullken et al. (1985) and in the 1984 KGS internal report do not coincide with Schoewe's (1949) physiographic boundaries between sections of the Central Lowland physiographic province. As in the case of the "Great Bend Prairie" aquifer, quotation marks are used in the designation of the "Equus beds" aquifer to indicate its misnomer status.

\section{Niobrara aquifer}

The Cretaceous Niobrara Chalk contains fracture and solution zones filled with water-saturated sand and gravel beneath the High Plains aquifer in northwestern Finney, eastern Kearny, and Scott counties (Latta, 1944; Waite, 1947; Gutentag et al., 1981). Most of the wells cited in Latta (1944) and Waite (1947) tap water supplies in the Smoky Hill Chalk Member of the Niobrara Chalk. Gutentag et al. (1981) reported that 1- to 2-ft-wide zones occur approximately 20 to $40 \mathrm{ft}$ above the base of the Fort Hays Limestone Member that are capable of supplying water at rates sufficient to meet or supplement the water needs of local irrigators. These zones generally occur along the western side of the Scott-Finney depression where the Niobrara is less than about $80 \mathrm{ft}$ thick (Bob Vincent, personal communication, 2000). Gutentag et al. (1981) referred to these sand- and gravel-filled cavities as the Chalk aquifer. The name Niobrara aquifer is more appropriate for this local aquifer because it more specifically identifies the geologic unit that constitutes the aquifer framework (Laney and Davidson, 1986).

\section{Dakota aquifer system}

The Dakota aquifer system (fig. 5) was coined by Macfarlane et al. (1990) to identify the sandstone aquifers in the Lower Cretaceous Dakota and Kiowa Formations and the Cheyenne Sandstone in Kansas. Macfarlane (1993) later extended this name to include sandstone aquifers in stratigraphically equivalent rock units in southeastern Colorado. Kume and Spinazola (1985) showed that hydraulic heads in the sandstone aquifers of the Dakota Formation are similar to hydraulic heads in the Cheyenne Sandstone over much of southwestern Kansas. This suggests that even though the sandstone aquifers are separated by a regional confining unit, they act together as a single hydraulic unit.

In Kansas the name Dakota aquifer system is used to identify, collectively, the sandstone aquifers in Lower Cretaceous rocks because the Dakota Formation is the primary aquifer unit within the system (Macfarlane, 1993). The Cheyenne Sandstone is a valley-fill deposit at the base of the Lower Cretaceous Series associated with incised paleovalley systems in older Jurassic and Permian rocks (Hamilton, 1994). Sandstones in the Cheyenne and in the 


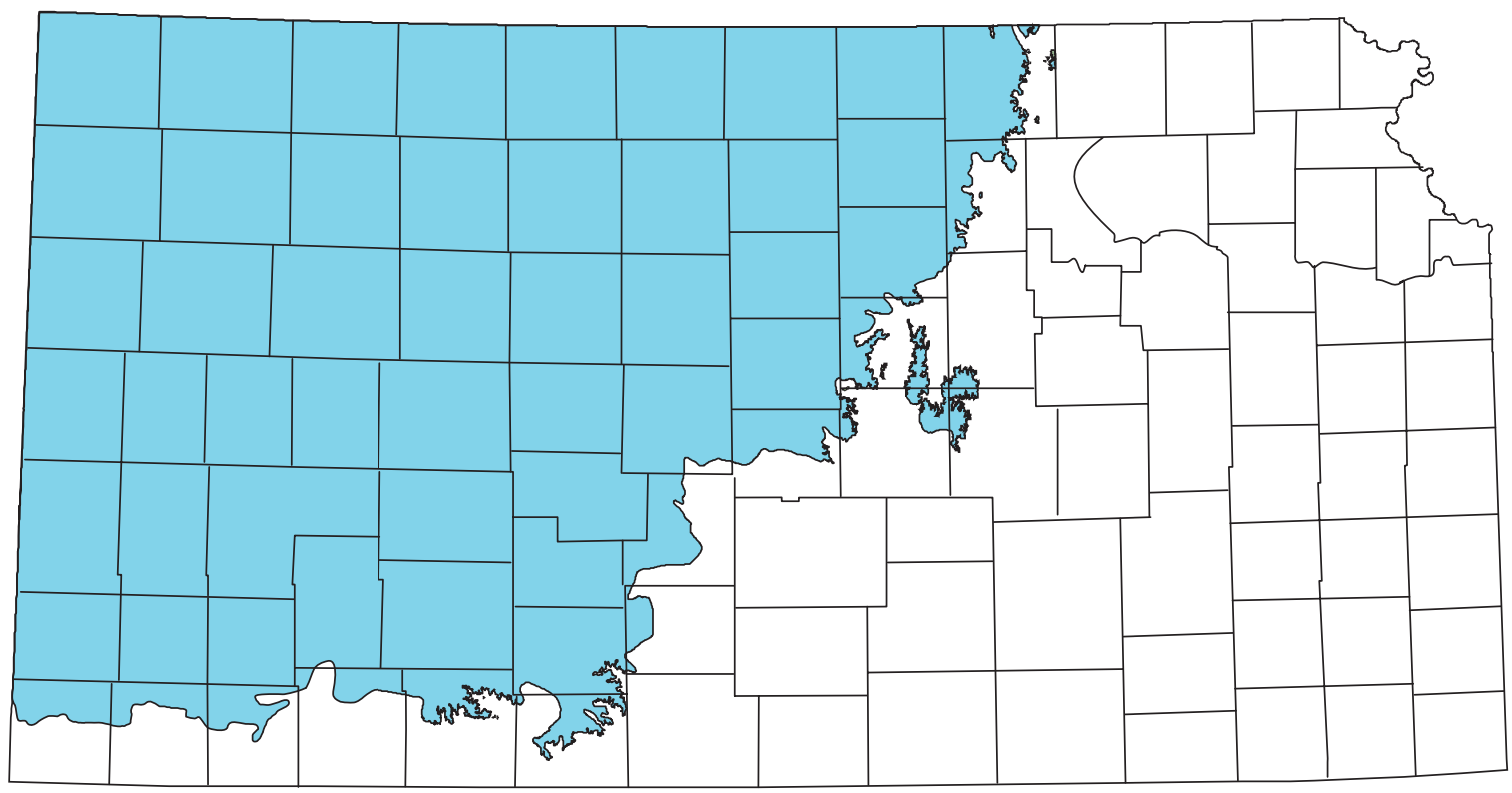

Figure 5. Extent of the Dakota aquifer system in Kansas.

overlying Kiowa are thin and of very limited extent. Thick, deltaic and shoreline sandstones are locally developed in the Longford Member (Kiowa Formation) and in Longford-equivalent Kiowa strata in the subsurface in central Kansas (Macfarlane et al., 1991). In contrast, sandstones in the Dakota Formation are widespread in Kansas because they were deposited on a broad, low-relief coastal plain adjacent to the developing Western Interior sea.

The name Dakota aquifer system should be retained because it is entrenched in the scientific literature for this part of the Great Plains region and is legally defined in the regulatory framework of Kansas. In the Darton (1906, p. 50) report on the hydrogeology of the Arkansas River valley in southeastern Colorado, the Dakota and associated sandstones were identified as the principal water-bearing formation of the region. In Kansas, Haworth (1913) emphasized that the Dakota sandstone was an important ground-water resource for the state. Moore (1940) discussed ground-water availability from sandstones in the Dakota group. Smith (1940) reported that the Dakota Sandstone was an important source of ground water in parts of southwestern Kansas. In the most recent rules and regulations of the Kansas Division of Water Resources (K.A.R. 5-1-1), the Dakota aquifer system is said to "include the Dakota formation, the Kiowa formation, the Cheyenne Sandstone, and, where hydraulically connected, the Morrison formation" (Kansas Department of Agriculture, 1999, p. 10).

Macfarlane et al. (1992) subdivided the Dakota aquifer system into the Upper Dakota and Lower Dakota aquifers. The Upper Dakota aquifer consists of sandstones in the
Dakota Formation, and the Lower Dakota aquifer consists of sandstones in the Longford Member (Kiowa Formation) and Cheyenne Sandstone. Over much of their extent in Kansas, these aquifers are separated by confining units consisting of a thick, marine shale sequence in the Kiowa Formation. Where this confining unit is not present, two regional aquifers are not distinguished and the waterbearing Lower Cretaceous sandstones are referred to as the Dakota aquifer. Laney and Davidson (1986) indicate that the modifiers, such as Upper and Lower may be used where the confining unit extent is well known. In southwest Kansas, aquifer units in the underlying Morrison Formation and Dockum Group are not separated from the Lower Dakota aquifer by significant confining units (Macfarlane et al., 1994) and perhaps could be considered part of the Lower Dakota aquifer.

The Dakota aquifer system in Kansas is considered equivalent to the Great Plains aquifer system, which was designated by Jorgensen and Signor (1981) for the multistate Central Midwest RASA project of the U.S. Geological Survey. The Upper and Lower Dakota aquifers are equivalent to the larger-scale Maha and Apishapa aquifer units, respectively, of Jorgensen and Signor (1981). One of the project goals in the Central Midwest RASA project was to differentiate regionally extensive aquifers and confining units within rock units whose relations and variability are complex and whose names may change from place to place within state boundaries and across state boundaries (Helgeson et al., 1993). Laney and Davidson (1986) indicate that naming an aquifer using a geographic name is reasonable where no lithostratigraphic name or combination of names is appropriate at that scale. 
Hence, the names Great Plains, Maha, and Apishapa are appropriate at the multistate level (fig. 1).

\section{Morrison-Dockum aquifer}

The Morrison Formation and the underlying Dockum Group contain water-saturated sandstones in Kansas and adjacent areas of Colorado and Oklahoma (fig. 6). The Morrison is present over much of western Kansas (Doveton and Chang, 1991), but the Dockum Group is believed present only in southwestern Kansas (Merriam, 1963). In southwestern Kansas, sandstones make up approximately 20 percent of the total thickness of these units and high-capacity wells typically are screened in these and the overlying water-bearing geologic units (Kume and Spinzola, 1985). Elsewhere in the state, these sandstone aquifers are not used as a source of water and are poorly known. The name Morrison-Dockum aquifer is appropriate because this aquifer consists of sandstone bodies in vertically adjacent geologic units that are hydraulically connected (Laney and Davidson, 1986).

\section{Day Creek aquifer}

In central Morton County, highly permeable zones exist in locally cavernous anhydrite and gypsum beds that are interbedded with shale in the Permian Day Creek Dolomite (Gutentag et al., 1981). Wells tapping these zones in the vicinity of Richfield, Kansas, typically flow at the surface with initial well yields ranging up to $1,000 \mathrm{gpm}$ (McLaughlin, 1942). Gutentag et al. (1981) referred to this permeable formation as the Gypsum aquifer, but the name Day Creek aquifer is more appropriate for this local aquifer because the name more specifically identifies the geologic unit that constitutes the aquifer framework (Laney and Davidson, 1986).

\section{Cedar Hills-upper Salt Plain aquifer}

The Cedar Hills-upper Salt Plain aquifer (fig. 7) consists of sandstones (medium to fine and feldspathic) interbedded with sandy mudstone of the Permian Cedar Hills Sandstone and the underlying uppermost part of the Salt Plain Formation. Sandstones in the Cedar Hills are mostly massive bedded, but they may exhibit horizontal stratification and even high-angle cross-stratification (Holdoway, 1978). Locally, more than 90 percent of this aquifer consists of loosely cemented sandstone.

\section{Wellington aquifer}

The Wellington aquifer (fig. 8) consists of extensively fractured shales of the Permian Wellington Formation, resulting from the dissolution of underlying halite and gypsum and anhydrite near the updip edge of the Hutchinson Salt Member of the Wellington Formation (Gogel, 1981). Because the aquifer consists only of rocks belonging to the Wellington Formation, the Wellington aquifer is an appropriate name.

\section{Flint Hills aquifer}

The Flint Hills aquifer (fig. 8) consists of the Permian limestones in the Chase and Council Grove Groups. The limestone aquifers in these rock units are sources of water for many springs (Macpherson, 1996; Sawin et al., 1999)

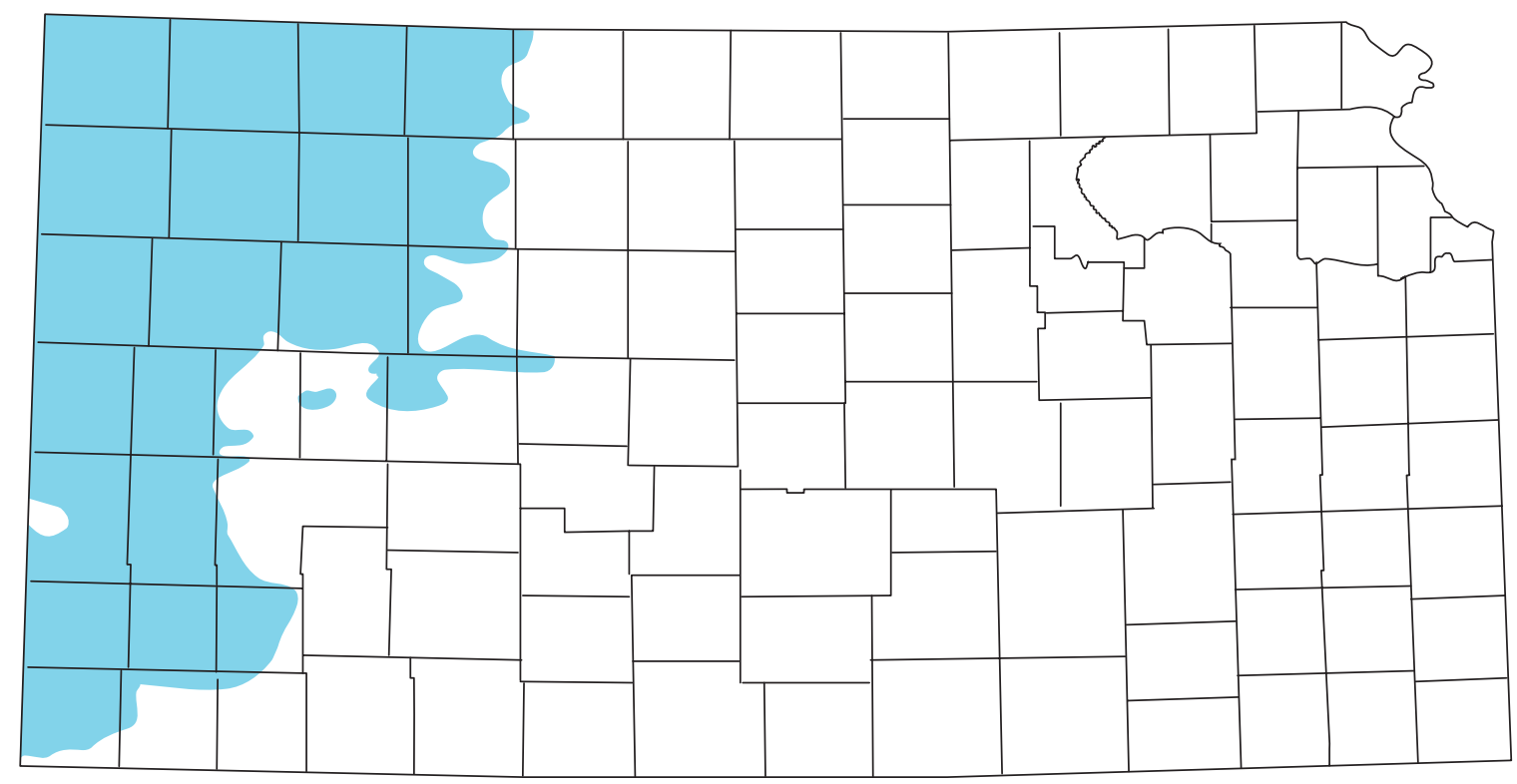

FIgURE 6. Extent of the Morrison-Dockum aquifer in Kansas. 


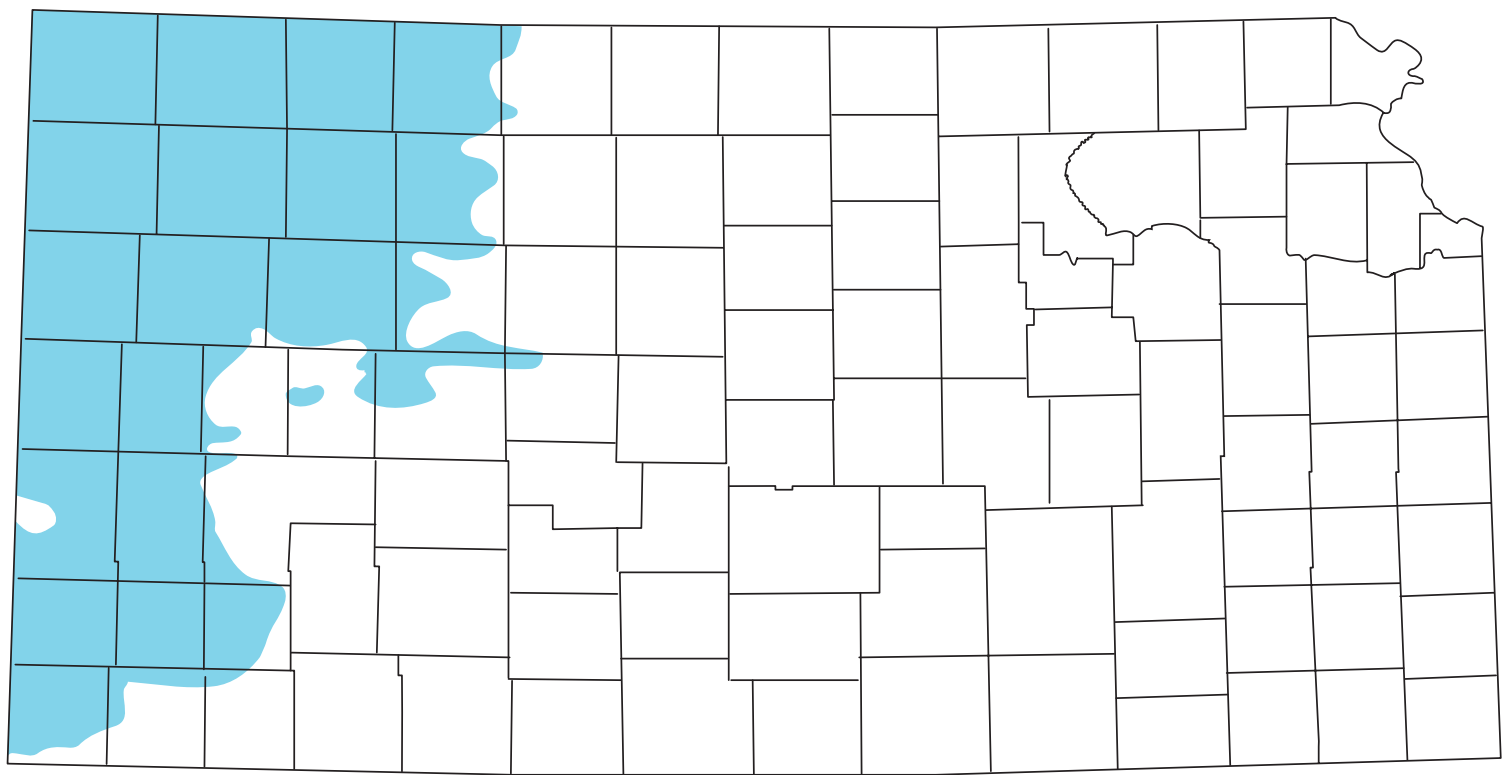

FIgURE 7. Extent of the Cedar Hills-upper Salt Plain aquifer in Kansas.

and for public water supply (O'Connor and Chaffee, 1983) throughout the Flint Hills region. Locally, well yields are estimated at up to $1,000 \mathrm{gpm}$ from the limestones that form this aquifer (Bayne, 1975).

The suggested aquifer name is based on the Flint Hills Upland division of the Central Lowlands physiographic province (Schoewe, 1949), and therefore follows the Laney and Davidson (1986) guidelines. The Flint Hills aquifer is an appropriate name because no single rock unit or combination of rock unit names meets the Laney and Davidson (1986) guidelines. Previously, this aquifer was referred to as the Chase and Council Grove aquifer (Sophocleous, 1998; U.S. Geological Survey, 1984), but this name is not appropriate because many of the limestone aquifer units contained in the Chase and Council Grove Groups are separated by regional confining units (Chaffee, 1988) and thus are not hydraulically connected.

\section{Osage Cuestas aquifer system}

The Osage Cuestas aquifer system (fig. 8) consists of the fluvial sandstones of the Pennsylvanian Tonganoxie Member (Stranger Formation) and the fluvio-deltaic sandstones of the Ireland Sandstone Member (Lawrence Formation). The upper and lower aquifer units are designated the Ireland aquifer and the Tonganoxie aquifer, respectively. These sandstones are believed to be hydraulically connected in southwestern Douglas County, where erosion removed the overlying strata of the Stranger Formation prior to deposition of the Ireland Sandstone (O'Connor, 1960). Elsewhere, the aquifers are separated by a confining unit consisting of shales belonging to the Lawrence shale. This aquifer system has been the main source of supply for many small communities, rural water districts, and farmsteads in Douglas, Franklin, Osage, Coffey, Montgomery, and Elk counties.

This aquifer system is named after the Osage Cuestas minor division of the Osage Plains section, Central Lowland physiographic province (Schoewe, 1949). In previous publications, this aquifer was referred to as the Douglas aquifer (Sophocleous, 1998; U.S. Geological Survey, 1984), but the new name, Osage Cuestas aquifer system, is based on a specific geographic entity, as recommended by Laney and Davidson (1986). The Tonganoxie and Ireland aquifers are named for members of the Stranger and Lawrence Formations, which is an appropriate use of lithostratigraphic names (Laney and Davidson, 1986).

\section{Ozark Plateau aquifer system}

As part of the Central Midwest RASA study of the U.S. Geological Survey, Jorgensen and Signor (1981) subdivided their project area into the Ozark and the Plains subregions. The Ozark subregion included the Ozarks of central and southern Missouri, northern Arkansas, and northeastern Oklahoma, as well as the southeastern corner of Kansas; the Plains subregion included the remainder of the project area to the west. The boundary separating these regions was chosen to coincide with a broad topographic low that extends in an arcuate manner from northeastern Oklahoma to the Missouri River in central Missouri. In the Ozark subregion, which includes the southeastern corner of Kansas, aquifers in Mississippian through Cambrian rock units were grouped together to form the Ozark Plateau aquifer system (fig. 9). As defined by Jorgensen and Signor (1981), the Ozark Plateau aquifer system consists of two aquifer units separated by a confining unit. 


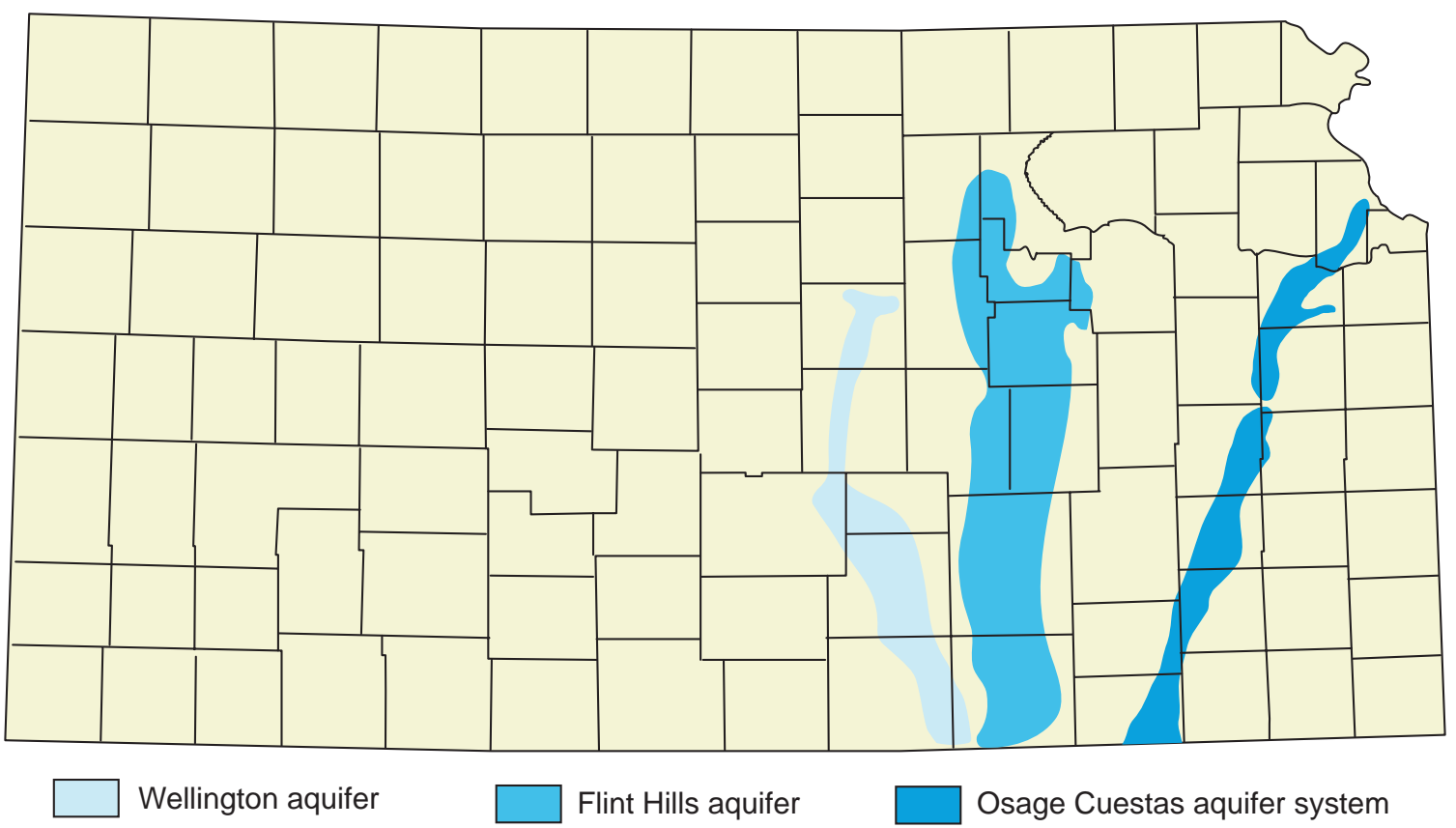

FIGURE 8. Extents of the Wellington and Flint Hills aquifers and the Osage Cuestas aquifer system.

The upper aquifer unit is the Springfield Plateau aquifer and it consists of the Mississippian St. Louis, Salem, Warsaw, Keokuk, and Fern Glen Limestones. The lower aquifer unit is the Ozark aquifer, which consists of the Lower Ordovician Cotter Dolomite, Jefferson City Dolomite, Roubidoux Formation, and Gasconade Dolomite, and the Cambrian Eminence Dolomite, Bonneterre Dolomite, and Reagan Sandstone. The Northview Shale, the Compton Limestone, and the Chattanooga Shale form the regional confining unit.

In the Plains subregion, Jorgensen et al. (1993) designated the Western Interior Plains aquifer system in carbonate rocks of Cambrian through Mississippian age on the basis of its distinctive hydrology. Ground-water flow in the Western Interior Plains aquifer system is eastward and comes from the deep sedimentary basins in Kansas, Nebraska, eastern Colorado, and Oklahoma. In contrast, the flow from the Ozark Plateau aquifer system is westward, radiating outward from the Ozarks uplands in southern Missouri.

Previously, the names used to identify aquifer units in these lower Paleozoic carbonates in Kansas were colloquially derived (Macfarlane and Hathaway, 1987). In southeast Kansas, where this aquifer system is a water supply, it is referred to as the Roubidoux after the Roubidoux Formation. Elsewhere in Kansas, where these aquifers are a source of hydrocarbons and not used as a source of drinking water, they are referred to collectively as the Arbuckle, after the Arbuckle Group. According to the Laney and Davidson (1986) guidelines, these names are inappropriate because other contributing aquifers in vertically adjacent hydraulically connected formations are not included in these colloquial names.
Hydrology is a poor basis on which to make distinctions between laterally adjacent regional systems that occupy the same hydraulically continuous lithostratigraphic units, such as the Western Interior Plains and the Ozark Plateau aquifer systems. The extent of the flow system may change with time due to pumping or injection stresses and climate change. Furthermore, because these aquifer units are used for various purposes (for water supply, hydrocarbons, and waste disposal), it is important to recognize their regional hydraulic continuity to protect usable ground water from contamination. Thus, it is recommended that the name Western Interior Plains aquifer system be abandoned and that the assemblage of stratigraphic units forming the framework of the Ozark Plateau aquifer system be expanded to include all of the Cambrian through Mississippian age lithostratigraphic units.

\section{Summary}

The aquifer nomenclature for Kansas outlined in this paper is based on the guidelines of Laney and Davidson (1986). These guidelines were based on discussions held between hydrogeologists and hydrologists in the Water Resources Division of the U.S. Geological Survey and represent a consensus of how best to apply names to hydrostratigraphic units. At present, there is no widely accepted code for hydrostratigraphic nomenclature, despite attempts to formally recognize these units in the North American Stratigraphic Code. Nevertheless, a hydrostratigraphic nomenclature, which defines clearly the stratigraphic units that form a given aquifer, is essential because a consistent nomenclature forms the basis of 


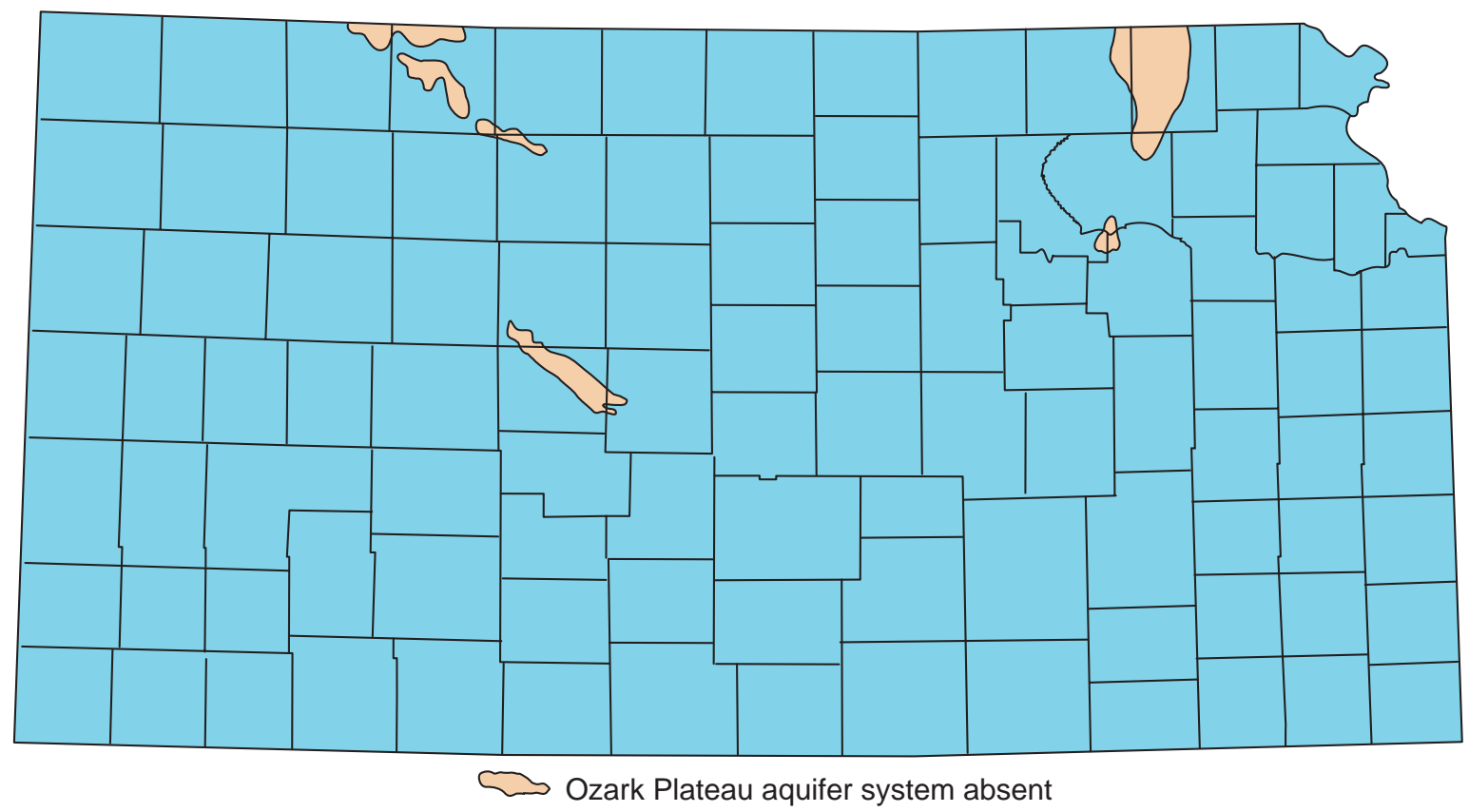

FIGURE 9. Extent of the Ozark Plateau aquifer system.

rational, scientific discussion of hydrologic issues. Just as important, many of the laws and regulations that pertain to ground water are based on aquifer designations and definitions. A common set of names may lessen the opportunity for erroneous or unintended hydrologic interpretations of Kansas laws and regulations.

\section{Acknowledgments}

I wish to thank my Kansas Geological Survey colleagues Margaret Townsend, Marios Sophocleous, Dave Young, Jeff Schloss, Don Whittemore, Bob Buddemeier, Rex Buchanan, and Dan Merriam for their comments on earlier drafts of this paper. These discussions have been valuable to me and have contributed greatly to my thoughts on this topic. I also wish to acknowledge the thoughtful reviews of Lloyd Stullken, Will Gilliland, and John Munson of the Division of Water Resources, Kansas Department of Agriculture, as well as Nathan Myers, Kansas District Office, U.S. Geological Survey. Their comments have helped strengthen this paper appreciably.

\section{References}

Aber, J. S., 1988, The glaciation of Kansas: Heritage of the Great Plains, v. 21, 36 p.

, 1991, The glaciation of northeastern Kansas: Boreas, v. 20, p. 297-314.

Adams, G. I., 1903, Physiographic divisions of Kansas: Kansas Academy of Science Transactions v. 18, pp. 109-123.

Baars, D. L., and Maples, C. G., 1998, Lexicon of Geologic Names of Kansas (through 1995)_A Compilation of the Geologic Names of Kansas: Kansas Geological Survey, Bulletin 231, $271 \mathrm{p}$.
Bayne, C. K., 1975, General availability of ground water and normal annual precipitation in Kansas: Kansas Geological Survey, Map M-4A, 1 sheet, scale 1:500,000.

Bayne, C. K., Boellstorff, J. D., and Miller, B. B., 1976, Guidebook-24th Annual Meeting, Midwestern Friends of the Pleistocene (Meade County, Kansas): Kansas Geological Survey, Guidebook Series 1, 85 p.

Chaffee, P., 1988, Effects of water-well construction on temporal variability of ground-water quality in Lincolnville, Marion County, Kansas: Kansas Geological Survey, Open-file Report 88-26, $171 \mathrm{p}$.

Darton, N. H., 1906, Geology and underground water resources of the Arkansas valley in eastern Colorado: U.S. Geological Survey, Professional Paper 52, 90 p.

Denne, J. E., Miller, R. E., Hathaway, L. R., O'Connor, H. G., and Johnson, W. C., 1998, Hydrogeology and geochemistry of glacial deposits in northeastern Kansas: Kansas Geological Survey, Bulletin 229, $127 \mathrm{p}$.

Doveton, J. H., and Chang, T., 1991, Latent facies mapping from binary geological data: Journal of Geology, v. 99, p. 299-309.

Fader, S., 1968, Ground water in the Republican River area, Cloud, Jewell, and Republic counties, Kansas: Kansas Geological Survey, Bulletin 188, 27 p.

Fader, S. W., and Stullken, L. E., 1978, Geohydrology of the Great Bend Prairie, south-central Kansas: Kansas Geological Survey, Irrigation Series 4, 19 p.

Fenneman, N. M., 1946, Physical subdivisions of the United States (Map): U.S. Geological Survey, 1:700,000, 1 sheet.

Fetter, C. W., 1994, Applied Hydrogeology, 3rd edition: New York, Macmillan College Publishing Co., 691 p.

Freeze, R. A., and Cherry, J. A., 1979, Ground Water: Englewood Cliffs, New Jersey, Prentice Hall Inc., 604 p.

Gogel, T., 1981, Discharge of saltwater from Permian rocks to major stream-aquifer systems in central Kansas: Kansas Geological Survey, Chemical Quality Series 9, 60 p.

Gutentag, E. D., and Weeks, J. B., 1980, Water table in the High 
Plains aquifer in 1978 in parts of Colorado, Kansas, Nebraska, New Mexico, Oklahoma, South Dakota, Texas, and Wyoming: U.S. Geological Survey, Hydologic Investigations Atlas HA-642.

Gutentag, E. D., Lobmeyer, D. H., and Slagle, S. E., 1981, Geohydrology of southwestern Kansas: Kansas Geological Survey, Irrigation Series 7, 73 p.

Hamilton, V. J., 1994, Sequence stratigraphy of Cretaceous Albian and Cenomanian strata in Kansas; in, Perspectives on the Eastern Margin of the Cretaceous Western Interior Basin, G. W. Shurr, G. A. Ludvigsen, and R. H. Hammond, eds.: Geological Society of America, Special Paper 287, p. 79-96.

Haworth, E., 1897, The geology of underground water in western Kansas: in, Kansas Board of Irrigation Survey and Experiment, Report for 1895 and 1896: Topeka, Kansas, The Kansas State Printing Company, p. 49-114.

Haworth, E., and Beede, J. W., 1897, The McPherson equus beds: Kansas Geological Survey, vol 2, p. 287-296.

Haworth, E., 1913, Special report on well waters in Kansas: Kansas Geological Survey Bulletin 1, 110 p.

Helgeson, J. O., Leonard, R. B., and Wolf, R. J., 1993, Aquifer systems underlying Kansas, Nebraska, and parts of Arkansas, Colorado, Missouri, New Mexico, Oklahoma, South Dakota, Texas, and Wyoming-Hydrology of the Great Plains aquifer system in Nebraska, Colorado, Kansas, and adjacent areas: U.S. Geological Survey, Professional Paper 1414-E, 161 p.

Holdoway, K., 1978, Deposition of evaporites and red beds of the Nippewalla Group, Permian, western Kansas: Kansas Geological Survey, Bulletin 215, 43 p.

Jackson, J. A., ed., 1997, Glossary of Geology (4 ${ }^{\text {th }}$ Edition): Alexandria, VA, American Geological Institute, 769 p.

Jorgensen, D. G., and Signor, D. C., 1981, Plan of study for the Central Midwest Regional Aquifer System Analysis in parts of Arkansas, Colorado, Kansas, Missouri, Nebraska, New Mexico, Oklahoma, South Dakota, and Texas: U.S. Geological Survey, Water-resources Investigations, Open-file Report 81-206, $28 \mathrm{p}$.

Jorgensen, D. G., 1982, Aquifer names: in, Geohydrology of the Dakota Aquifer, D.G. Jorgensen and D.C. Signor, eds.: Proceedings of the First C. V. Theis Conference on Geohydrology, Lincoln, Nebraska, p. 4-7.

Jorgensen, D. G., Helgeson, J. O., and Imes, J. L., 1993, Aquifer systems underlying Kansas, Nebraska, and parts of Arkansas, Colorado, Missouri, New Mexico, Oklahoma, South Dakota, Texas, and Wyoming-Geohydrologic framework: U.S. Geological Survey, Professional Paper 1414-B, 238 p.

Kansas Department of Agriculture, 1999, Proposed rules and regulations of the Division of Water Resources, Kansas Department of Agriculture: Topeka, Kansas Department of Agriculture, $256 \mathrm{p}$.

Kume, J., and Spinazola, J. M., 1985, Geohydrology of sandstone aquifers in southwestern Kansas: Kansas Geological Survey, Irrigation Series 8, $49 \mathrm{p}$.

Laney, R. L., and Davidson, C. R., 1986, Aquifer-nomenclature guidelines: U.S. Geological Survey, Open-file Report 86-534, $46 \mathrm{p}$.

Latta, B. F., 1941, Geology and ground-water resources of Stanton County, Kansas: Kansas Geological Survey, Bulletin $37,119 \mathrm{p}$.

1944, Geology and ground-water resources of Finney and Gray counties, Kansas: Kansas Geological Survey, Bulletin 55, $272 \mathrm{p}$.

Lohman, S. W., and others, 1972, Definitions of selected ground- water terms-Revisions and conceptual refinements: U.S. Geological Survey, Water-Supply Paper 1988, 9 p.

Macfarlane, P. A., 1993, The effect of topographic relief and hydrostratigraphy on the upper part of the regional groundwater flow system in southeastern Colorado and western and central Kansas, with emphasis on the Dakota aquifer: Ph.D. thesis, University of Kansas, Lawrence, 197 p.

Macfarlane, P. A., and Hathaway, L. R., 1987, The hydrogeology and chemical quality of ground waters from the lower Paleozoic aquifers in the Tri-State region of Kansas, Missouri, and Oklahoma: Kansas Geological Survey, Ground-water Series 9, $37 \mathrm{p}$.

Macfarlane, P. A., Wade, A., Doveton, J. H., and Hamilton, V. J., 1991, Revised stratigraphic interpretation and implications for pre-Graneros paleogeography from test-hole drilling in central Kansas: Kansas Geological Survey, Open-file Report 91-1A, $73 \mathrm{p}$.

Macfarlane, P. A., Doveton, J. H., Feldman, H. R., Butler, J. J., Jr., Combes, J. M., and Collins, D. R., 1994, Aquifer/aquitard units of the Dakota aquifer system in Kansas: methods of delineation and sedimentary architecture effects on groundwater flow and flow properties: Journal of Sedimentary Research, v. B64, no. 4, pp. 464-480.

Macfarlane, P. A., Whittemore, D. O., Townsend, M. A., Doveton, J. H., Hamilton, V. J., Coyle, W. G., III, and Wade, A., 1990, The Dakota Aquifer Program annual report, FY89: Kansas Geological Survey, Open-file Report 90-27, 302 p.

Macfarlane, P. A., Whittemore, D. O., Chu, T., Butler, J. J., Jr., Wade, A., Coleman, J., Doveton, J. H., Mitchell, J. E., and Kay, S., 1992, The Dakota Aquifer Program annual report, FY91: Kansas Geological Survey, Open-file Report 92-1, $93 \mathrm{p}$.

Macpherson, G. L., 1996, Hydrogeology of thin limestones-The Konza prairie long-term ecological research site, northeastern Kansas: Journal of Hydrology, v. 186, p. 191-228.

Maxey, G. B., 1964, Hydrostratigraphic units: Journal of Hydrology, v. 2, p. 124-129.

McLaughlin, T. G., 1942, Geology and ground-water resources of Morton County, Kansas: Kansas Geological Survey, Bulletin 40, $126 \mathrm{p}$.

Merriam, D. F., 1963, The geologic history of Kansas: Kansas Geological Survey, Bulletin 162, 317 p.

Moore, R. C., 1940, Ground-water resources of Kansas: Kansas Geological Survey, Bulletin 27, 112 p.

NACSN (North American Commission on Stratigraphic Nomenclature), 1983, North American Stratigraphic code: American Association of Petroleum Geologists, Bulletin, v. 67 , no. 5, p. 841-875.

O'Connor, H. G., 1960, Geology and ground-water resources of Douglas County, Kansas: Kansas Geological Survey, Bulletin $148,200 \mathrm{p}$.

O'Connor, H. G., and Chaffee, P. K., 1983, Geohydrology field trip, Marion County, Kansas: Kansas Geological Survey, Open-file Report 83-25, 42 p.

O'Connor, H. G., and McClain, T. J., 1981, Geologic and hydrologic characteristics of the Ogallala and peripheral aquifers in western Kansas: Kansas Geological Survey, Openfile Report 81-10, 137 p., 10 maps.

Poland, J. F., Lofgren, B. E., and Riley, F. S., 1972, Glossary of selected terms useful in studies of the mechanics of aquifer systems and land subsidence due to fluid withdrawal: U.S. Geological Survey, Water Supply Paper 2025, 9 p.

Sawin, R. S., Buchanan, R. C., and Lebsack, W., 1999, Flint Hills 


\section{Macfarlane}

springs: Kansas Academy of Science Transactions, v. 102, p. $1-31$.

Schoewe, W. H., 1949, The geography of Kansas: Kansas Academy of Science Transactions. v. 52, no. 3, p. 261-333.

Seaber, P. R., 1988, Hydrostratigraphic units: in, Hydrogeology, W. Back, J. R. Rosenshein, and P. R. Seaber, eds.: The Geology of North America, Geological Society of America, vol. O-2, p. 9-14.

Self, H., 1978, Environment and man in Kansas: The Regents Press of Kansas, Lawrence, 288 p.

Smith, H. T. U., 1940, Geologic studies in southwestern Kansas: Kansas Geological Survey, Bulletin 34, 212 p.

Sophocleous, Marios, 1998, Water resources of Kansas-A comprehensive outline; in, Perspectives on Sustainable Development of Water Resources in Kansas, Marios Sophocleous, ed.: Kansas Geological Survey, Bulletin 239, p. 3-59.

Steeples, D. W., and Buchanan, R., 1983, Kansas geomaps: Kansas Geological Survey, Educational Series 4, 30 p.
Stramel, G. J., 1956, Progress report on the ground-water hydrology of the Equus Beds area, Kansas: Kansas Geological Survey, Bulletin 119, part 1, p. 1-59.

Stullken, L. E., Watts, K. R., and Lindgren, R. J., 1985, Geohydrology of the High Plains aquifer, western Kansas: U.S. Geological Survey, Open-file Report 85-4198, 86 p.

U.S. Geological Survey, 1985, National water summary 1984: U.S. Geological Survey Water-Supply Paper 2275, 467 p.

Waite, H. A., 1947, Geology and ground-water resources of Scott County, Kansas: Kansas Geological Survey, Bulletin 66, $216 \mathrm{p}$.

Williams, C. C., and Lohman, S. W., 1949, Geology and groundwater resources of a part of south-central Kansas: Kansas Geological Survey, Bulletin 79, 455 p.

Wilson, F. W., 1978, Kansas landscapes-A geologic diary: Kansas Geological Survey, Educational Series 5, 50 p.

Zeller, D. E. ed., 1968, The stratigraphic succession in Kansas: Kansas Geological Survey, Bulletin 189, 81 p. 